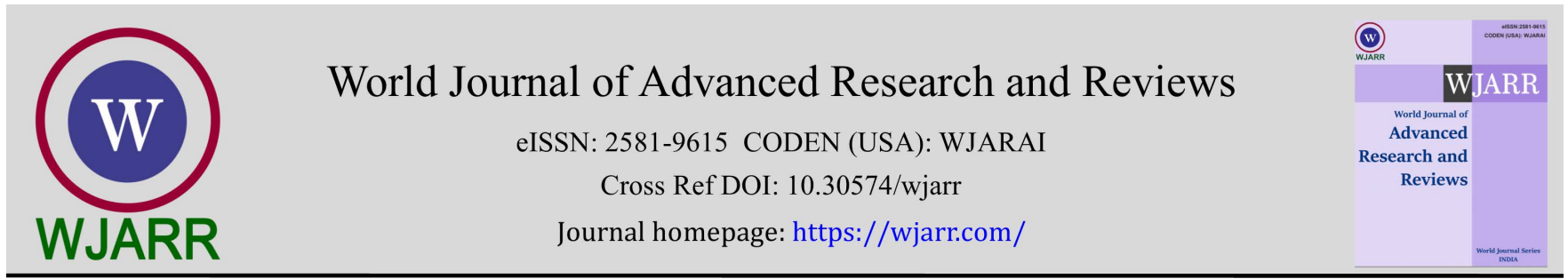

(RESEARCH ARTicle)

Check for updates

\title{
Effect of cassava-legume intercropping systems on productivity and cassava insect pests population dynamics across three major agro-climatic zones of Sierra Leone
} \author{
Yomeni ${ }^{3}$ \\ ${ }^{1}$ Natural Resource Management, Njala Agricultural Research Center, Sierra Leone. \\ ${ }^{2}$ Fourah Bay College, University of Sierra Leone. \\ ${ }^{3}$ International Institute of Tropical Agriculture (IITA), PMB 5320, Ibadan, Nigeria.
}

Augustine Mansaray ${ }^{1, *}$, Abdul Babatunde Karim ${ }^{2}$, Thomas B R Yormah ${ }^{2}$, Abdul Rahman Conteh ${ }^{1}$ and Marie

World Journal of Advanced Research and Reviews, 2021, 12(03), 285-295

Publication history: Received on 21September 2021; revised on 11 December 2021; accepted on 13 December 2021

Article DOI: https://doi.org/10.30574/wjarr.2021.12.3.0474

\begin{abstract}
Field trials were conducted in 2015/2016 and 2016/2017 cropping seasons in three agro-climatic zones of the country to evaluate the productivity and insect pests population dynamics of cassava as a response to spatial arrangement, plant architecture and cropping systems. The treatments consisted of seven cropping associations, two cassava architectures and two spatial arrangements. The study reveals that yield parameters of cassava were higher in cassava-soybean system at all locations. The number of marketable roots and forage yield were on average higher when the erect cassava variety was intercropped with the legumes using the $1 \mathrm{~m} \mathrm{x} 1 \mathrm{~m}$ spatial arrangement. On the other hand, root yield and canopy width were higher when the $2 \mathrm{~m} \times 0.5 \mathrm{~m}$ spatial arrangement and the branched cassava architecture was used respectively. In general, yield parameters were higher at Segbwema expect for forage yield that was higher at Makeni. With respect to cassava insect pests, higher percentage incidences and severity scores were recorded on sole cassava and when the branched cassava variety was intercropped with legumes using the $2 \mathrm{~m} \times 0.5 \mathrm{~m}$ spatial arrangement of cassava. In addition, cassava insect pests incidences were only observed at 6 MAP and 9MAP and were higher in Segbwema compared to the other locations. Thus, in order to improve productivity of cassava with low insect pest infestation, the erect cassava variety should be intercropped with soybean at a spatial arrangement of $1 \mathrm{~m} \times 1 \mathrm{~m}$.
\end{abstract}

Keywords: Intercropping; Spatial arrangement; Population dynamics; Agro-climatic zone; Incidence; Severity score

\section{Introduction}

Cassava, Manihot esculenta Grantz (Euphorbiaceae), is an important food crop for over 22800 million people in the World [1]. In Sierra Leone, cassava is the second staple food after rice and has increasingly become a strategic commodity for food economy as consumption has expanded beyond the traditional rural production areas into towns and cities of the country. Small-scale farmers generally cultivate it as a subsistence crop in a diverse range of cropping systems [2]. Grain legumes such as cowpea, groundnut and soybean are known to fix nitrogen into the soil, through the process called biological nitrogen fixation (BNF). Biological nitrogen fixation (BNF) in legumes is a fundamental process for maintaining soil fertility and hence leads to the continued productivity of low-input cropping systems. In Sierra Leone, cassava is found in a variety of crop production systems and performs well under various levels of management. Studies carried out by [3] have shown that intercropping grain legumes with cassava could improve the overall productivity of the system. In addition to increased productivity, this system in most cases results in a decrease in insect pests, weeds and disease severity [4] due to increase in biodiversity, alteration of the microclimatic conditions of neighboring plants and also altering the host plant quality [5]. According to [6] considerable evidence has emerged over the past twenty years to suggest that pest populations and problems are much greater in crops grown in monoculture

*Corresponding author: Augustine Mansaray; E-mail:augumans@yahoo.co.uk
Natural Resource Management, Njala Agricultural Research Center, Sierra Leone.

Copyright (@) 2021 Author(s) retain the copyright of this article. This article is published under the terms of the Creative Commons Attribution Liscense 4.0. 
than those grown with intercropping as one of the component crops may act as a physical barrier thus reducing the lateral spread of pests. In most African countries including Sierra Leone, intensive agricultural activity coupled with rapid population growth and limited nutrient inputs have resulted in the decline of fertility [7]. In order to maintain soil fertility and improve crop yields, intercropping which has been a common practice of smallholder farmers could be one of the existing integrated soil fertility management options that should be adopted by smallholder farmers. Thus, for an intercropping system to be efficient and productive, each crop must have sufficient space to maximize cooperation and reduce competition between them. For this to be realized, four things need to be considered: spatial arrangement, plant density, maturity dates of the crops being grown, and plant architecture [8]. [9] have shown that spatial arrangement in intercropping is an important management practice that can improve interception of radiation. Thus to improve productivity in intercropping system there is a need to reduce intra-specific competition between the component crops for limiting growth resources such as solar radiation [10] or nutrients [11]. In Sierra Leone, information on the effect of cropping systems, on productivity and insect pest population of cassava is scanty. The objective of this research therefore is to examine the effect of cassava-legume based cropping systems on productivity and insect pests population dynamics of cassava in agro-ecosystems where cassava is intercropped with legumes.

\section{Materials and methods}

\subsection{Study Area}

The study was conducted between 2015-2017 under rain fed condition in three Agro-climatic zones namely Sumbuya in Bo district representing the forest transition with annual rainfall of $2,616.6 \mathrm{~mm}$, temperature of $37.4^{\circ \mathrm{C}}$, and a relative humidity of $75 \%$, Makeni in Bombali district representing the derived savannah with annual rainfall $1121 \mathrm{~mm}$, temperature of $30^{\circ \mathrm{C}}$ and a relative humidity of $77 \%$ and Segbwema in Kailahun district representing the forest region with annual rainfall of $2476.5 \mathrm{~mm}$, temperature of $37.4^{0 \mathrm{C}}$ and relative humidity of $76.7 \%$. The soils at Makeni, Sumbuya and Segbwema were sandy clay loam, and sandy loam in texture respectively.

\subsection{Land preparation}

The land at the three locations was slashed with cutlass, burnt, destumped and dug using hoe and the plots laid out using measuring tape, garden line and pegs.

\subsection{Experimental design, treatments and planting}

The experiment was laid out in a spilt-split block design with three replications. The treatments consisted of seven cropping associations (sole cassava, sole groundnut, sole cowpea, sole soybean, cassava + cowpea, cassava + groundnut and cassava + soybean), two cassava architectures (branched and erect) and two spatial arrangements ( $1 \mathrm{~m} \times 1 \mathrm{~m}$ and $2 \mathrm{~m} \times 0.5 \mathrm{~m}$ ). The plot size will be $7 \mathrm{~m} \times 6 \mathrm{~m}$. The trials were conducted for two consecutive years 2014/2015 and 2016/ 2017 respectively. The cassava and the three legumes were planted on flat in June of each year. Stem cuttings of about $25 \mathrm{~cm}$ long with five nodes of each cassava variety was used. Cassava was planted at the spacings of $1 \mathrm{~m} \times 1 \mathrm{~m}$ and $2 \mathrm{~m}$ x $0.5 \mathrm{~m}$ respectively; whilst cowpea and groundnut were planted at the spacing of $50 \mathrm{~cm}$ x $20 \mathrm{~cm}$ with two seeds per hole for cowpea and one seed per hole for groundnut. On the other hand, soybean was planted at the spacing of $50 \mathrm{~cm}$ $\mathrm{x} 10 \mathrm{~cm}$ with two seeds per hole. The legumes were introduced in between the rows of the cassava. The cassava varieties used were slicass 6 that is the erect type and slicass 1, which is the branched type. The cowpea, soybean and groundnut varieties used were IITA573k-1-1, Slibean 2 and Slinut 1 respectively. Weeding was done with hoe at one, three and six months after planting. Cassava was harvested at 12 months after planting whilst the three legumes were harvested at their different maturity dates. The haulms of the harvested legumes were returned into the cassava system after harvest.

\subsection{Data collection}

The yield parameters determined were number of marketable root, root yield and forage yield. Forage yield was determined by weighing the tender stem and leaves using a sensitive scale. This was later expressed in $\mathrm{t} / \mathrm{ha}$. Root yield was determined by harvesting all the cassava plants within the net plot followed by detachment of all the storage roots from the stump and weighing using a salter scale. Root yield was also expressed in $t / h a$. The storage roots per treatments were sorted based on whether they were marketable of not. A storage root was considered marketable when it weighs between 100-400g. Insect pest data were collected on 10 randomly selected tag plants per plot at 3, 6, 9 and 12 months after planting. The insect pest data collected were percentage incidence and severity of cassava green mite (Mononychellus tanajoa) and grasshopper (Zonocerus variegatus). These were the two dominant cassava insect pests during the growing seasons at the three locations. Percentage incidence was expressed as the total number of infected cassava plant over the total number of cassava plants randomly sampled whilst, severity score was expressed as a percentage of the total area of the cassava plant tissue affected over the total area of the plant tissue [12]. Grasshopper 
severity was estimated using the visual rating scale of 1-5 per individual plant; where: $1=0-20 \%$ of foliage consumed, $2=21-40 \%$ of foliage consumed, $3=41-60 \%$ of foliage consumed, $4=61-80 \%$ of foliage consumed and $5=81$ $100 \%$ of foliage consumed [13]. Severity score of cassava green mite was assessed using the five-point scale where 1 represents no visible symptom and 5 severe symptom expression [14].

\subsection{Data analysis}

All data collected were subjected to analysis of variance (ANOVA) using the SAS statistical package [15] and means were compared using the Student Newman-Keuls Test (SNK) at 0.05 level of significance. Data for insect counts were square root transformed [16] before analysis.

\section{Results}

\subsection{Number of marketable root}

Analysis using ANOVA reveals significant differences $(\mathrm{P}<0.05)$ in the number of marketable root among cropping systems at Segbwema and Sumbuya; however, there were no significant differences $(\mathrm{P}>0.05)$ in marketable roots in Makeni across the cropping systems (Table 1). Generally, cassava-soybean cropping system recorded the highest number of marketable roots (8.84-28.38) followed by the sole cassava (7.56-27.4), cassava-groundnut (8.6418.55)whilst the cassava- cowpea cropping system recorded the least (6.99-17.05) across the three locations (Table 1). The number of marketable roots was 13\%, 25\% and 22\% higher in Makeni, Segbwema and Sumbuya respectively in cassava- soybean cropping system compared to the other cropping systems. For location, significant differences were recorded in the number of marketable roots with Segbwema recording significantly $(\mathrm{P}<0.05)$ the highest $(22.25)$ followed by Sumbuya (16.42) and Makeni(8.01). In the case of spatial arrangement, significant differences were not recorded in the number of marketable roots across all locations even though the $1 \mathrm{~m} \times 1 \mathrm{~m}$ spatial arrangement registered slightly higher values across all locations. The mean number of marketable roots for the $1 \mathrm{mx} 1 \mathrm{~m}$ spatial arrangement ranged from (9.14-26.59) whilst the $2 \mathrm{~m} \times 0.5 \mathrm{~m}$ spatial arrangement range from (6.29-22.73) across the three locations (Table 1). With regards to plant architecture, significant differences $(P<0.05)$ were recorded in the number of marketable roots across all three locations (Table 1). The cassava variety with the erect plant architecture on average recorded significantly $(\mathrm{P}<0.05)$ the highest number marketable roots compared to the one with the branched architecture. In addition, the three-way interactions among cropping system, spatial arrangement $\mathrm{x}$ plant architecture on number of marketable roots at the three locations were not significant $(\mathrm{P}>0.05)$.

\subsection{Root yield}

Root yield was significantly different $(\mathrm{P}<0.05)$ across cropping systems at all locations with the cassava-soybean cropping system registering the highest root yield whilst cassava-cowpea cropping system recorded the least across all locations (Table 1). The root yield for cassava-soybean cropping system ranged from (15.23-30.89) compared to sole cassava (12.69-27.07), cassava-groundnut (15.05-20.97) and cassava-cowpea (11.01-20.51). Cassava-soybean cropping system root yield was 11\%,19\% and 20\% higher at Makeni, Segbwema and Sumbuya respectively compared to the other cropping systems. There were however no significant differences in root yield between the sole cassava and the cassava-groundnut intercrop even though the sole cassava recorded slightly higher yields in Segbwema (20.07) and Sumbuya (17.02). About location, root yield was generally higher in Segbwema (25.11) followed by Sumbuya (16.42) whilst Makeni recorded the least (13.49) (Table 1). Relating to spatial arrangement, no significant differences $(\mathrm{P}>0.05)$ were recorded with respect to root yield across locations; however, the $2 \mathrm{~m} \times 0.5 \mathrm{~m}$ spatial arrangement registered a slightly higher root yield across the three locations compared to the $1 \mathrm{~m} \times 1 \mathrm{~m}$ spatial arrangement (Table 1). Similarly, root yield was not significantly different $(P>0.05)$ with respect to plant architecture however; the cassava variety with the erect architecture out yielded the cassava variety with the branched architecture at all locations (Table 1).

\subsection{Forage yield}

Forage yield was significantly different $(\mathrm{P}<0.05)$ across the cropping systems with cassava-soybean cropping system again recording the highest across the three locations. Forage yield for the cassava-soybean cropping system was $15 \%$, 35\% and 25\% higher at Makeni, Segbwema and Sumbuya respectively compared to the other cropping systems. (Table 1). At Makeni, the forage yield for the sole cassava, cassava-soybean and cassava-groundnut systems were not significantly different $(\mathrm{P}>0.05)$ from each other but were different from the cassava-cowpea system. On the other hand, at Sumbuya and Segbwema, the forage yield for the sole cassava, cassava-groundnut and cassava-cowpea intercropping systems were not significantly different $(\mathrm{P}>0.05)$ from each other but were different from the cassava-soybean system (Table 1). In the case for location, Makeni recorded the highest forage yield (10.50) followed by Sumbuya (7.96) and 
Segbwema (7.94). Relating to spatial arrangement, significant differences $(\mathrm{P}>0.05)$ were not recorded with respect to forage yield even though, the $1 \mathrm{mx} 1 \mathrm{~m}$ spatial arrangement recorded slightly higher forage yields across the three locations compared to the $2 \mathrm{~m} \times 0.5 \mathrm{~m}$ spatial arrangement (Table 1). With respect to plant architecture, significant differences in forage yield were only observed in Segbwema where in, the cassava variety with the branched architecture recorded significantly $(\mathrm{P}<0.05)$ higher value $(9.11)$ compared to the cassava with the erect architecture (6.43). At Makeni and Sumbuya, significant differences $(P>0.05)$ were not observed in forage yield but the cassava with the branched architecture recorded slightly higher values at both locations (Table 1). Furthermore, the three-way interactions among cropping systems x plant architecture $\mathrm{x}$ spatial arrangement with respect to forage yield at the three agro-climatic zones were not significant $(\mathrm{P}>0.05)$.

\subsection{Cassava green mite incidence and severity}

Mean percentage cassava green mite incidence was significantly different $(\mathrm{P}<0.05)$ among cropping systems. On the other hand, it was not significantly different $(\mathrm{P}>0.05)$ with respect to spatial arrangement and plant architecture (Table 2). Cassava mite incident was generally moderate ranging from $47.71 \%-54.68 \%, 45.84 \%-49.06 \%$ and $50.18 \%-50.78 \%$ 185 for cropping system, spatial arrangement and plant architecture respectively (Table 2). For cropping system, the sole cassava (54.69\%) recorded a significantly higher percentage incidence of the cassava green mite followed by cassava-cowpea (50.59\%), cassava-groundnut (49.110\%) and cassava-soybean (47.71\%) cropping system. There were however no significant differences ( $\mathrm{P}>0.05)$ in percentage green mite incidences among cassava-groundnut, cassavacowpea and cassava-soybean cropping systems. (Table 2). With respect to location, percentage green mite incidence was also moderate ranging from $35.85 \%$ to $-57.69 \%$. Segbwema (58.72\%) was observed to have recorded the highest percentage of cassava green mite followed by Makeni (49.61\%) whilst Sumbuya (43.27\%) recorded the least. Furthermore, it was observed that the highest percentage incidence of green mite was recorded at all locations at 9 MAP which correspond to March followed by 6 MAP (December) and 12MAP (June). No cassava green mite incidence was recorded at $3 \mathrm{MAP}$ at all the experimental locations.

Concerning spatial arrangement, a slightly higher percentage incidence was obtained when the $2 \mathrm{~m} \times 0.5 \mathrm{~m}$ cassava spatial arrangement (49.06\%) was used compared to the $1 \mathrm{~m}$ x $1 \mathrm{~m}$ spatial arrangement (45.84\%). Pertaining to plant architecture, the branched cassava architecture recorded a slightly higher percentage green mite incidence (50.78\%) compared to the erect cassava variety $(50.18 \%)$. In addition, it was observed that the three-way interactions among cropping system $\mathrm{x}$ spatial arrangement $\mathrm{x}$ plant architecture with respect to percentage green mite incidence at all locations were not significant $(\mathrm{P}>0.05)$. About cassava green mite severity score, no significant differences $(\mathrm{P}>0.05)$ were registered with respect to cropping system, spatial arrangement and plant architecture. In addition, severity scores were generally low and were not significantly different $(\mathrm{P}>0.05)$ across locations except in the case for spatial arrangement for cassava where Segbwema recorded a slight significant difference in severity score (Table 2). Also, as with percentage incidence, the highest severity score for all locations was recorded in March followed by December, June and September respectively.

\subsection{Grasshopper incidence and severity}

Percentage grasshopper incidence was significantly different $(\mathrm{P}<0.05)$ with respect to cropping system but was not significantly different about spatial arrangement and plant architecture. Percentage incidence was generally moderate ranging from 30.68\%-39.98\% for cropping system, 34.44\%-36.73\% for spatial arrangement and 35.88-36.78 for plant architecture (Table 3). In the case for cropping system, the sole cassava was observed to have recorded higher incidences of grasshopper (39.98\%) compared to the other cropping systems. However, there were no significant differences in mean percentage incidence of grasshopper among the cassava-soybean, cassava-groundnut and cassavacowpea intercropping systems. 
Table 1 Effect of cropping systems (CS), spatial arrangement of Cassava (SA) and Plant architecture of Cassava (PA) on yield and yield components of Cassava with respect to location over a two year cropping season

\begin{tabular}{|c|c|c|c|c|c|c|c|c|c|c|}
\hline \multicolumn{11}{|c|}{ Locations } \\
\hline & \multicolumn{3}{|c|}{ Makeni } & \multicolumn{3}{|c|}{ Segbwema } & \multicolumn{3}{|c|}{ Sumbuya } & \\
\hline \multirow[t]{2}{*}{ Parameter } & \multicolumn{3}{|c|}{ Yield parameter $(\mathrm{t} / \mathrm{ha})$} & \multicolumn{3}{|c|}{ Yield parameter $(\mathrm{t} / \mathrm{ha})$} & \multicolumn{3}{|c|}{ Yield parameter $(\mathrm{t} / \mathrm{ha})$} & \multirow[t]{2}{*}{ Mean } \\
\hline & $\begin{array}{l}\text { Number of } \\
\text { marketable } \\
\text { root }\end{array}$ & $\begin{array}{l}\text { Root } \\
\text { yield }\end{array}$ & $\begin{array}{l}\text { Forage } \\
\text { yield }\end{array}$ & $\begin{array}{l}\text { Number of } \\
\text { marketable } \\
\text { root }\end{array}$ & $\begin{array}{l}\text { Root } \\
\text { yield }\end{array}$ & $\begin{array}{l}\text { Forage } \\
\text { yield }\end{array}$ & $\begin{array}{l}\text { Number of } \\
\text { marketable } \\
\text { root }\end{array}$ & $\begin{array}{l}\text { Root } \\
\text { yield }\end{array}$ & $\begin{array}{l}\text { Forage } \\
\text { yield }\end{array}$ & \\
\hline \multicolumn{11}{|l|}{ Cropping system } \\
\hline $\begin{array}{l}\text { Cassava- } \\
\text { groundnut }\end{array}$ & $8.64 \mathrm{a}$ & $15.04 \mathrm{a}$ & $10.91 \mathrm{a}$ & $18.55 \mathrm{a}$ & $21.50 \mathrm{~b}$ & $6.70 \mathrm{~b}$ & $13.39 \mathrm{~b}$ & $16.04 \mathrm{a}$ & $7.09 \mathrm{~b}$ & $13.06 \mathrm{~b}$ \\
\hline Cassava-cowpea & $6.99 \mathrm{a}$ & $11.01 \mathrm{~b}$ & $8.34 \mathrm{~b}$ & $17.05 \mathrm{~b}$ & $20.97 \mathrm{~b}$ & $6.82 \mathrm{~b}$ & $13.60 \mathrm{~b}$ & $11.98 \mathrm{~b}$ & $7.33 \mathrm{~b}$ & $11.62 b$ \\
\hline Cassava-soybean & $8.84 \mathrm{a}$ & $15.23 a$ & $12.39 \mathrm{a}$ & $28.03 a$ & $30.89 \mathrm{a}$ & $10.70 \mathrm{a}$ & $20.03 \mathrm{a}$ & $20.60 \mathrm{a}$ & $9.54 a$ & $17.04 \mathrm{a}$ \\
\hline Sole cassava & $7.56 \mathrm{a}$ & $12.69 \mathrm{ab}$ & $10.27 \mathrm{a}$ & $25.38 \mathrm{a}$ & $27.07 \mathrm{ab}$ & $7.53 b$ & $18.66 \mathrm{a}$ & $17.02 \mathrm{a}$ & $7.87 \mathrm{~b}$ & $15.18 \mathrm{a}$ \\
\hline Mean & $8.01 \mathrm{c}$ & $13.49 \mathrm{c}$ & $10.47 \mathrm{a}$ & $22.25 \mathrm{a}$ & $25.11 \mathrm{a}$ & $7.94 \mathrm{~b}$ & $16.42 \mathrm{~b}$ & $16.42 \mathrm{~b}$ & $7.96 \mathrm{~b}$ & \\
\hline \multicolumn{11}{|c|}{ Spatial arrangement } \\
\hline $1 \mathrm{~m} \times 1 \mathrm{~m}$ & $9.14 \mathrm{a}$ & $13.05 \mathrm{a}$ & $10.98 \mathrm{a}$ & $26.59 \mathrm{a}$ & $25.56 a$ & $8.31 \mathrm{a}$ & $19.05 \mathrm{a}$ & $15.68 \mathrm{a}$ & $8.61 \mathrm{a}$ & $15.21 \mathrm{a}$ \\
\hline $2 \mathrm{~m} \times 0.5 \mathrm{~m}$ & $6.29 \mathrm{a}$ & $13.42 \mathrm{a}$ & $10.02 \mathrm{a}$ & $22.73 \mathrm{a}$ & $25.81 \mathrm{a}$ & $7.15 \mathrm{a}$ & $15.33 \mathrm{~b}$ & $17 . .63 a$ & $7.86 \mathrm{a}$ & $14.02 \mathrm{a}$ \\
\hline Mean & $7.72 \mathrm{c}$ & $13.24 \mathrm{c}$ & $10.50 \mathrm{a}$ & $24.66 \mathrm{a}$ & $25.68 \mathrm{a}$ & $7.73 \mathrm{~b}$ & $17.19 \mathrm{~b}$ & $16.66 \mathrm{~b}$ & $8.24 \mathrm{~b}$ & \\
\hline \multicolumn{11}{|c|}{ Plant architecture } \\
\hline Erect & $9.84 \mathrm{a}$ & $14.26 \mathrm{a}$ & $10.40 \mathrm{a}$ & $28.71 \mathrm{a}$ & $26.50 \mathrm{a}$ & $6.43 \mathrm{~b}$ & $22.25 \mathrm{a}$ & $18.34 \mathrm{a}$ & $7.09 \mathrm{a}$ & $15.99 \mathrm{a}$ \\
\hline Branch & $5.41 \mathrm{~b}$ & $11.89 \mathrm{a}$ & $10.53 a$ & $20.00 \mathrm{~b}$ & $24.71 \mathrm{a}$ & $9.11 \mathrm{a}$ & $12.82 \mathrm{~b}$ & $15.05 \mathrm{a}$ & $8.73 \mathrm{a}$ & $13.12 \mathrm{~b}$ \\
\hline Mean & $7.63 \mathrm{c}$ & $13.08 \mathrm{c}$ & $10.47 \mathrm{a}$ & $24.36 \mathrm{a}$ & $25.61 \mathrm{a}$ & 7.77 b & $17.54 \mathrm{~b}$ & $16.69 \mathrm{~b}$ & $7.91 \mathrm{~b}$ & \\
\hline
\end{tabular}


Table 2 Effect of cropping systems (CS), spatial arrangement of Cassava (SA) and Plant architecture of Cassava (PA) on cassava green mite incidence and severity with respect to location over a two year cropping season

\begin{tabular}{|c|c|c|c|c|c|c|c|c|}
\hline \multirow[b]{3}{*}{ Parameter } & \multicolumn{4}{|c|}{ Cassava green mite incidence $(\%)$} & \multicolumn{4}{|c|}{ Cassava green mite severity sore } \\
\hline & \multicolumn{3}{|c|}{ Location } & \multirow[b]{2}{*}{ Mean } & \multicolumn{3}{|c|}{ Location } & \multirow[b]{2}{*}{ Mean } \\
\hline & Makeni & Segbwema & Sumbuya & & Makeni & Segbwema & Sumbuya & \\
\hline \multicolumn{9}{|l|}{ Cropping system } \\
\hline Cassava- groundnut & 47.75 & 56.93 & 42.67 & $49.11 \mathrm{~b}$ & 1.54 & 1.66 & 1.48 & $1.56 \mathrm{a}$ \\
\hline Cassava-cowpea & 50.93 & 56.18 & 44.66 & $50.59 \mathrm{~b}$ & 1.56 & 1.46 & 1.53 & $1.51 \mathrm{a}$ \\
\hline Cassava-soybean & 45.80 & 58.25 & 39.10 & $47.71 \mathrm{~b}$ & 1.48 & 1.75 & 1.47 & $1.56 \mathrm{a}$ \\
\hline Sole cassava & 53.95 & 63.50 & 46.63 & $54.69 \mathrm{a}$ & 1.80 & 1.75 & 1.53 & $1.69 \mathrm{a}$ \\
\hline Mean & $49.61 \mathrm{~b}$ & $58.72 \mathrm{a}$ & $43.27 \mathrm{~b}$ & & $1.60 \mathrm{a}$ & $1.63 \mathrm{a}$ & $1.50 \mathrm{a}$ & \\
\hline \multicolumn{9}{|l|}{ Spatial arrangement } \\
\hline $1 \mathrm{mx} 1 \mathrm{~m}$ & 47.16 & 55.95 & 34.41 & $45.84 \mathrm{a}$ & 1.53 & 1.70 & 1.49 & $1.57 \mathrm{a}$ \\
\hline $2 \mathrm{~m} \times 0.5 \mathrm{~m}$ & 50.46 & 59.44 & 37.27 & $49.06 \mathrm{a}$ & 1.66 & 1.74 & 1.52 & $1.64 \mathrm{a}$ \\
\hline Mean & $48.81 b$ & $57.69 \mathrm{a}$ & $35.85 \mathrm{c}$ & & $1.60 \mathrm{~b}$ & $1.72 \mathrm{a}$ & $1.51 \mathrm{~b}$ & \\
\hline \multicolumn{9}{|l|}{ Plant architecture } \\
\hline Erect & 50.04 & 57.77 & 44.54 & $50.78 \mathrm{a}$ & 1.58 & 1.67 & 1.49 & $1.58 \mathrm{a}$ \\
\hline Branch & 48.20 & 58.78 & 43.56 & $50.18 \mathrm{a}$ & 1.61 & 1.75 & 1.51 & $1.62 \mathrm{a}$ \\
\hline Mean & $49.12 \mathrm{~b}$ & $58.28 \mathrm{a}$ & $44.07 \mathrm{~b}$ & & $1.60 \mathrm{a}$ & $1.71 \mathrm{a}$ & $1.50 \mathrm{a}$ & \\
\hline
\end{tabular}

Furthermore, a highly significant locational difference $(\mathrm{P}<0.05)$ in percentage incidence was observed with Segbwema registering a higher mean percentage incidence (43.36\%) compared to Sumbuya (36.08\%) and Makeni (27.365\%). In addition, grasshopper incidences were observed only in December and March, which corresponds to 6MAP and 9MAP respectively (Table 3). Grasshopper incidences were not observed in September and June at all locations. Grasshopper incidence was higher in March at all locations compared to December. Relating to spatial arrangement, slightly higher incidences were recorded on the $2 \mathrm{~m}$ x $0.5 \mathrm{~m}$ spatial arrangement of cassava (36.73\%) compared to the $1 \mathrm{~m} \times 1 \mathrm{~m}$ spatial arrangement (34.44\%). For plant architecture, the branched cassava variety was observed to have attracted a slightly higher incidence (36.78\%) compared to the erect (35.88\%) cassava variety (Table 3). Also, the three-way interactions among cropping system $\mathrm{x}$ spatial arrangement $\mathrm{x}$ plant architecture with respect to grasshopper incidences at all locations were not significant $(\mathrm{P}>0.05)$. Concerning grasshopper severity score, significant differences $(\mathrm{P}<0.05)$ were only observed concerning cropping system (Table 3 ). There were however, no significant differences (P>0.05) with respect to spatial arrangement and architecture of cassava even though the $2 \mathrm{~m} \times 0.5 \mathrm{~m}$ spatial arrangement registered a slightly higher value (1.49) compared to the $1 \mathrm{~m} \mathrm{x1} \mathrm{m} \mathrm{(1.42).} \mathrm{For} \mathrm{plant} \mathrm{architecture,} \mathrm{the} \mathrm{erect} \mathrm{cassava} \mathrm{variety} \mathrm{recorded}$ a slightly higher value (1.51) compared to the branching type (1.46). In general, severity scores were low across cropping system, spatial arrangement and plant architecture (Table 3). About cropping system, the sole crop registered a significantly $(\mathrm{P}<0.05)$ higher severity score $(1.62)$ compared to cassava-soybean (1.33), cassava-cowpea (1.46) and cassava-groundnut (1.42) systems. Conversely, significant differences $(\mathrm{P}>0.05)$ in severity score were not recorded among cassava-cowpea, cassava-soybean and cassava-ground systems. Also, as with percentage incidence, severity scores were higher in March compared to December at all locations (Table 3). Also, the three-way interactions among cropping systems $\mathrm{x}$ spatial arrangement $\mathrm{x}$ plant architecture with respect to grasshopper severity score were not significant all locations $(\mathrm{P}>0.05)$. 
Table 3 Effect of cropping systems (CS), spatial arrangement of Cassava (SA) and Plant architecture of Cassava (PA) on grasshopper incidence and severity with respect to location over a two year cropping season

\begin{tabular}{|c|c|c|c|c|c|c|c|c|}
\hline \multirow[b]{3}{*}{ Parameter } & \multicolumn{3}{|c|}{ Grasshopper incidence } & \multicolumn{5}{|c|}{ Grasshopper severity sore } \\
\hline & \multicolumn{3}{|c|}{ Location } & \multirow[b]{2}{*}{ Mean } & \multicolumn{3}{|c|}{ Location } & \multirow[b]{2}{*}{ Mean } \\
\hline & Makeni & Segbwema & Sumbuya & & Makeni & Segbwema & Sumbuya & \\
\hline \multicolumn{9}{|c|}{ Cropping system } \\
\hline $\begin{array}{l}\text { Cassava- } \\
\text { groundnut }\end{array}$ & 24.40 & 39.55 & 34.22 & $\begin{array}{c}32.72 \\
a b\end{array}$ & 1.40 & 1.44 & 1.43 & $1.42 \mathrm{~b}$ \\
\hline $\begin{array}{l}\text { Cassava- } \\
\text { cowpea }\end{array}$ & 28.65 & 40.44 & 38.11 & $\begin{array}{c}35.73 \\
\mathrm{ab}\end{array}$ & 1.42 & 1.42 & 1.53 & $1.46 \mathrm{~b}$ \\
\hline $\begin{array}{l}\text { Cassava- } \\
\text { soybean }\end{array}$ & 25.28 & 41.80 & 24.97 & $30.68 \mathrm{~b}$ & 1.31 & 1.41 & 1.26 & $1.33 \mathrm{~b}$ \\
\hline Sole cassava & 33.19 & 45.04 & 41.71 & $39.98 \mathrm{a}$ & 1.61 & 1.63 & 1.62 & $1.62 \mathrm{a}$ \\
\hline Mean & $27.88 \mathrm{c}$ & $41.71 \mathrm{a}$ & $34.75 \mathrm{~b}$ & & $1.44 \mathrm{a}$ & $1.45 \mathrm{a}$ & $1.46 \mathrm{a}$ & \\
\hline \multicolumn{9}{|c|}{$\begin{array}{l}\text { Spatial } \\
\text { arrangement }\end{array}$} \\
\hline $1 \mathrm{mx} 1 \mathrm{~m}$ & 26.51 & 41.71 & 35.11 & $34.44 \mathrm{a}$ & 1.34 & 1.41 & 1.51 & $1.42 \mathrm{a}$ \\
\hline $2 \mathrm{~m} \times 0.5 \mathrm{~m}$ & 28.20 & 45.00 & 37.04 & $36.73 \mathrm{a}$ & 1.45 & 1.46 & 1.56 & $1.49 \mathrm{a}$ \\
\hline Mean & $27.36 \mathrm{c}$ & $43.36 \mathrm{a}$ & $36.08 \mathrm{~b}$ & & $1.40 \mathrm{a}$ & $1.44 \mathrm{a}$ & $1.54 \mathrm{a}$ & \\
\hline \multicolumn{9}{|c|}{ Plant architecture } \\
\hline Erect & 25.88 & 42.47 & 41.93 & $36.78 \mathrm{a}$ & 1.36 & 1.46 & 1.71 & $1.51 \mathrm{a}$ \\
\hline Branch & 28.03 & 42.83 & 36.79 & $35.88 \mathrm{a}$ & 1.43 & 1.49 & 1.45 & $1.46 \mathrm{a}$ \\
\hline Mean & $26.96 \mathrm{~b}$ & $42.65 \mathrm{a}$ & $39.36 \mathrm{a}$ & & $1.40 \mathrm{a}$ & $1.48 \mathrm{a}$ & $1.58 \mathrm{a}$ & \\
\hline
\end{tabular}

Severity score: $1=0-20 \%$ of foliage consumed, $2=21-40 \%$ of foliage consumed, $3=41-60 \%$ of foliage consumed, $4=61-80 \%$ of foliage consumed and $5=81-100 \%$ of foliage

\section{Discussions}

\subsection{Effect of cropping system, spatial arrangement and plant architecture on the yield parameters of cassava.}

The study reveals significant variations in the number of marketable roots among cropping systems at Segbwema and Sumbuya. In general, higher number of marketable roots was obtained for the cassava-soybean cropping systems among all locations compared to the sole cassava and the other cropping systems. The above observation could be probably due to better photosynthetic efficiency and the good soil moisture level created by the cassava-soybean intercropping system compared to the other cropping systems. In addition, cassava tuber initiation and bulking were not subjected to any intercrop competition, as the soybean was harvested earlier before tuberization process commenced in cassava [17]. Several authors including [18] in a cassava-legume intercrop, [19] in a cassava-groundnut intercrop and [20] in a cassava okra intercrop have reported positive effects of intercropping on the number of cassava marketable root and other yield related components of cassava relative to the sole cassava. On the other hand, the number of marketable roots was on average higher for the sole cassava compared to the cassava-groundnut and cassava-cowpea systems across the three locations. The decrease in the number of marketable roots when cassava was intercropped with groundnut and cowpea could be attributed to competition for the available growth resources. Thus, it is possible that the peak demand for growth resources of these crops could have coincided thus, resulting in competition that led to significant reduction in the number of marketable roots. This result concord with the findings of [21] who reported that the number of marketable roots can be reduced by intercropping. Furthermore, the higher number of marketable roots recorded with respect to the erect cassava variety could be attributed to the genotypic characteristic of the cassava variety used and also the fact that the erect cassava architecture grows faster in height and were generally not subjected to competition relative to the associated crop. Relating to root yield, significant variations 
were recorded among cropping systems at all locations. Higher root yields were recorded by the cassava-soybean system compared to sole cassava and the other cropping systems. The higher root yield observed under cassavasoybean intercrop could be because soybean is a short duration crops, which matured just after maximum canopy development and harvested, earlier before tuber bulking process commence. This result is in agreement with [22] who reported higher yield and yield related components of cassava in the intercropping system compared to the sole cassava. These authors suggested that intercropping cassava with legumes were beneficial to the Cassava as the legume will enriched the soil by improving the nitrogen status of the soil as the legume can fix nitrogen into the soil [23, 24]. This result is in direct contrast with the findings of [25]. These authors reported higher cassava root yield when cassava was intercropped with groundnut compared to cassava-cowpea and cassava-soybean systems. Similar findings relating to the superiority of cassava-groundnut intercropping over cassava- soybean and cassava- cowpea systems was also reported by [26]. These results suggest that the productivity of an intercrop system will vary with component species as well as the environment. The recorded increased in root yield of cassava intercropped with grain legumes have also been reported by $[27,21]$. This result suggests that the presence of legumes in the cassava-legume mixtures may have been beneficial to cassava crop. The beneficial effects of legumes stem from their enriching soil by improving the soil nitrogen status, as legumes have the ability to fix nitrogen into the soil $[23,28]$. Another factor that can be implicated for the significant yield differences is the increase in soil organic matter (SOM) in the cassava-legume mixture, resulting from the decomposition of biomass produced by cassava and the legumes [29].

The result further shows that root yield for the sole cassava was higher relative to cassava-groundnut and cassavacowpea systems. The cowpea based cropping system caused 22\%- 30\% cassava root reduction whilst the Cassavagroundnut based system caused 6\%- $30421 \%$ yield reduction at Segbwema and Sumbuya respectively. The reduction in yield and yield-related components of cassava intercropped with groundnut and cowpea relative to the sole cassava could have been due to both inter and intraspecific completion for growth resources such as light, water and nutrients by both intercrop components. [30] had reported similar competitive interactions among intercrop species such as soybean and sorghum. Other possible reason for the low yield and yield related components of cassava in the intercropping systems could be due to the low establishment percentage of cassava in intercropping systems compared to the sole. Pertaining to spatial arrangement, significant differences were not recorded concerning root yield. This result conforms to the findings by [31] as reported by [32] show that root yields of three cassava cultivars do not differ for the $1 \mathrm{~m} \times 1 \mathrm{~m}$ or the $2 \mathrm{~m} \times 0.5 \mathrm{~m}$ arrangement. The slightly higher yields recorded about the $2 \mathrm{~m} \times 0.5 \mathrm{~m}$ spatial arrangement of cassava could probably be because this arrangement tends to enhanced more transmission of light to the shorter crops as suggested by [33]. In addition, concerning plant architecture, significant differences were recorded in root yield. The higher root yield recorded by the erect cassava variety could be explained by the fact that the erect variety grew faster in height and as such was not affected by competition for light relative to the associated crop. Forage yield, which includes the leaves and the tender stem, was significantly different among cropping systems and location, which contradicts the findings of [34]. These authors reported no significant effect on forage yield when cassava was intercropped with legumes. Cassava forage yield was consistently higher for the cassava-soybean system across the three locations compared to the sole crop and the other cropping systems. This observation is in contrast with the study conducted by [35] in which he reported a $24 \%$ reduction in forage yield of cassava when it was intercropped with $F$. microphylla compared to the sole cassava. The higher cassava forage yield reported for the cassava-soybean system could be related to the fact that this system was able to efficiently utilize the environmental resources more efficiently compared to the sole cassava and the other cropping system. On the other hand, the reported higher forage yield for the sole cassava compared to the cassava-cowpea and the cassava-groundnut systems could be related probably to both inter and intra specific completion between the component crops. This result agrees with the findings of [35]. Furthermore, higher forage yield was recorded at Makeni compared to the other two locations. On the other hand, forage yield was not significantly different with respect to spatial arrangement although slightly higher values were recorded for the $1 \mathrm{~m} \times 1 \mathrm{~m}$ spatial arrangement compared to that of the $2 \mathrm{~m} \times 0.5 \mathrm{~m}$ arrangement. The slightly higher value recorded for the $1 \mathrm{~m} \times 1 \mathrm{~m}$ arrangement could probably be related to the fact that the intra plant distance between the $2 \mathrm{~m} \times 0.5 \mathrm{~m}$ spatial arrangement was smaller compared to the $1 \mathrm{~m} \times 1 \mathrm{~m}$ spatial arrangement thus, resulting into more intra plant competition for growth resources such as space and light which probably led to mutual shading resulting into the reduction of incidence light reaching the plants thus reducing the rate of photosynthesis and the subsequent decrease in value of the measured parameter. In the case for plant architecture, the slightly higher value of forage yield recorded for the branched variety could probably be due to the genetic characteristic of the variety. This variety is a highly branched variety and as such produces higher forage compared to the erect variety.

\subsection{Effect of cropping system, spatial arrangement and plant architecture on incidence and severity of cassava insect pests}

Both cassava green mite and grasshopper were present in the three agro climatic zones with incidences raging from low to moderate. Severity was generally low for both pests. Significant differences were observed among cropping 
system across the three locations with respect to cassava green mite and grasshopper. This result is in contrast to the findings of [36] in the case for cassava green mite. For both pests, higher incidences and severity were recorded for the sole cassava compared to the other intercropping systems. This result agrees with the findings of other scientist who have indicated that insect pest populations were suppressed in intercropping systems compared to monocultures [37]. Moreover, [38] in his work involving pest species showed that the population of insect pests in intercropping systems was lower in $35852 \%$ of the studies compared to monocultures. According to [39] the reason for the reduction of pest population in intercropping systems could be due to three possible mechanisms including the destructive- crop hypothesis, the trap crop hypothesis and the natural enemy hypothesis. According to the disruptive-crop hypothesis, the presence of a second non-suitable host plant attracts the pest away from its primary host. Thus, according to [40] when an herbivore comes into contact with a non-host, it use up additional time and energy in locating an acceptable plant which reduces the time and energy of the insect for crop damage and in some instances, it encourages the insect to migrate from the area. The natural enemy hypothesis on the other hand states that lower pest density in intercropping systems may be due to the action of natural enemies in intercropping system. [38, 37] reported that diverse agro ecosystem created by multiple cropping tend to increase the number of natural enemies. Furthermore, [37] opined that the rate of parasitism by Diaeretiella rapae on cabbage aphid was higher in intercropping plots compared with homogenous crops. Also, [41,42] reported a considerable reduction in maize yield losses due to $S$. calamistis in maize intercropped with cassava or grain legumes. From the result the possible reasons for the lower number of insect pests in the intercropping system compared to that of the sole could probably be due to the combined effects of both the natural enemy and the disruptive crop hypotheses. The result further suggests higher incidence and severity of both pests at 6 MAP and 9 MAP, which corresponds to December and March respectively. This could be because the populations build-up of these pest starts at the closure of the rainy season, which is December, and the peak of the dry season which is March. For most insect pest, population increase is a function of temperature hence the high populations of both pests in December and March. On the other hand, cassava green mite and grasshoppers were not observed at 3 MAP and 12 MAP respectively. The observed low incidence and severity of the pests during the rainy season could be related probably to the low temperature, which reduces, developmental rate of the pest and also due to the fact that rain is one of the natural mortality factors of the pests. This observation corroborates with the findings of $[43,44,45]$. These authors reported negative correlation between rainfall and mite incidence and severity. Furthermore, both grasshopper and mite incidences and severity were higher at Segbwema compared to the other locations because of the variations in the environmental variables such as rainfall, temperature and relative humidity across the locations which might have probably resulted into the differences in the survival and perpetuation of the pests among the zones.

\section{Conclusion}

The study has revealed that yield parameters such as number of marketable roots, root yield and forage yield were significantly higher with cassava-soybean intercropping system compared to the other cropping systems across all locations. The number of marketable roots and forage yield were higher with the $1 \mathrm{~m} \times 1 \mathrm{~m}$ spatial arrangement whilst root yield was higher with the $2 \mathrm{~m}$ x $0.5 \mathrm{~m}$ spatial arrangement of cassava. On average, number of marketable roots and root yield were higher when the erect cassava variety was used. However, higher forage yield was recorded when the branched variety was used. The yield parameters were generally higher at Segbwema compared to the other locations. Relating to cassava insect pests, percentage incidence and severity scores were generally higher in the sole cassava compared to the intercropped. No significant differences were recorded with respect to spatial arrangement and plant architecture even though slightly higher values were recorded with respect to the $2 \mathrm{~m} \times 0.5 \mathrm{~m}$ spatial arrangement and the branched cassava architecture. In general, pest incidence and severity were only observed at MAP and 9MAP and were higher in Segbwema compared to the other locations.

\section{Compliance with ethical standards}

\section{Acknowledgments}

Many thanks to AFDB for funding the SARD-SC project and to all my supervisors for their support.

\section{Disclosure of conflict of interest}

Authors who include Augustine Mansaray, Abdul Babatunde Karim, Thomas Yormah, Abdul Rahman Conteh and Marie Yormeni have declared that no competing interests exist. 


\section{References}

[1] Mbanzibwa DR, Tian YP, Tugume A K, Patil B L, Yadav J S, Bagewadi B,Valkonen JP T. Evolution of cassava brown streak-associated viruses. Journal of General Virology. 2011; 92: 974-987.

[2] Alves BJR, Boddey RM, Urquiaga S. The success of BNF in soybean in Brazil. Plant Soil. 2003; 252:1-9.

[3] Ogola BO, Mathews C, Magongwa SM. The productivity of cassava-legume intercropping system in a dry environment in Nelspruit, South Africa. African Crop Science 421 Conference Proceedings. 2013; 11: 61-65.

[4] Amanullah MM, Somasundaram E, Vaiyapuri K, Sathyamoorthi K. Intercropping in cassava-a review, Agric. Rev. 2007; 28: 179-187.

[5] Langer V, Kinane J, Lyngkjær M. Intercropping for pest management: The ecological concept. In: Koul O, Cupreus GW (eds) Ecologically Based Integrated Pest Management.CABI Publishing, Wallingford, UK. 2007.

[6] Gabriele, S. Natural crop protection in the tropic.

[7] Kang BT. Introduction to alley farming, in Tripathi, B.R., and Psychas PJ. The AFNETA alley farming training manual: Source book for alley farming research. 1992; 429(2): IITA.

[8] Grossman J, William Q. Strip intercropping for biological control. IPM Practitioner. April. 1993; 1-11.

[9] Heitholt JJ, Farr JB, Eason R. Plant configuration and cultivar environments. Crop Science. 2005; 45: 1800-1808.

[10] Banik P, Sharma R C. Yield and resource utilization efficiency in baby corn-legume. Intercropping System in the Eastern Plateau of India. Journal of Sustainable Agriculture. 2009; 33:379-395.

[11] Dahmardeh M, Ghanbar A, Syahsar BA, Ramrodi M. The role of intercropping maize (Zea mays L.) and cowpea (Vigna unguiculata L.) on yield and soil chemical properties, Afr. J. Agric. Res. 2010; 5: 631-636.

[12] Mansaray A, Samura AE, Conteh AR, Quee DD. Survey on the occurrence and distribution of major cassava arthropod pests in Sierra Leone. Journal of Biology and Nature. 2020,; 12(1) : 7-17.

[13] Capinera JL. Host-plant selection by Schistocerca americana (Orthoptera: Acrididae). Environ. Entomol. 1993; 22:127-133.2020; 12(1): 7-17, 2020

[14] Nukenine E N, Hassen AT, Dixon AGO, Fokunang CN. Population dynamics of cassava greenmite. Mononychellus tanajoa (Bondar) (Acari:Tetranychidae) as influenced by varietal resistance. Pak. J. Biol. Sci. 2002; 5:177-183.

[15] SAS Institute. The SAS system for windows. Release 9.4. Cary. NC. USA; 2014.

[16] Steel RGD, Torrie JH. Principles and procedures of statistics. A biometrical approach, 2nd ed. McGraw-Hill, New York. 1980.

[17] Fukai S, Tsay JS, Wilson G L, Cenpukdee U, Grady DPS. Cassava-legume intercropping in the subtropics. In. Howeler, R.H. (Ed.). Proc. of 8th Symposium for Tropical root crops, ISTRC, Thailand. 1990; 293-300.

[18] Polthanee A, Wanapat S, Wanapat M, Wachirapokorn C .Cassava-Legumes intercropping: A potential food-feed system for dairy farmers, in International Workshop on Current Research and Development on Use of Cassava as Animal Feed, Khon Kaen University, Thailand. 2001; 23-24.

[19] Dung TT. FPR trials on cassava intercropping and weed control in Vietnam. 7th Regional Cassava Workshop, 28th October-1st November 2002. Bangkok, Thailand.

[20] Mbah EU, Anyim A, Ogidi E, Ubani SI .Effect of contrasting cassava genotypes on growth, population dynamics of podagrica sjostedti and yield of okra in cassava/okra intercropping under the rain forest agroecology of southeast Nigeria. Glob. J. Agric. Sci. 2011; 9(2):49-56.

[21] Ijoyah MO, Bwala RI, Iheadindueme CA. Response of cassava, maize and melon in a three crop intercropping system at Makurdi, Nigeria. Int. J. Dev. and Sust. 2012; 1:135-144.

[22] Kurtz LA. The yield and yield indices of cassava as affected by increasing planting densities of cowpea in a cassava- cowpea mixture. Crop Husbandry Research. 2006; 1: 90 -469 95

[23] Kim BT. Influence of cassava interplanted with soybean on soil chemical properties and yield of cassava. Soil and Crop Science. 2005; 4 (3): $608-613$.

[24] Aigh BF. The role of tropical legumes in improving soil fertility and crop production. Plant and Soil Science. 2007; 3: $224-229$. 
[25] Eke-Okoro ON, Ikeorgu JEG, Okorocha EOA. Comparative evaluation of five legume species for soil fertility improvement, weed suppression and component crop yields in cassava/legume intercrops. Afr. J. Root Tuber Crops. 1999; 3: 54-57.

[26] Pypers P, Sanginga JM, Kasereka B, Walangululu M, Vanlauwe B. Increased productivity through integrated soil fertility management in cassava-legume intercropping systems in the highlands of Sud-Kivu, DR Congo. Field Crops Res. 2011; 120:76-85.

[27] Udeata RO. Effects of increasing groundnut planting densities in a cassava-groundnut intercrop on yield and yield components of cassava in Northeastern Zimbabwe. Journal of Agricultural Science and Environment. 2005; 3(2): $266-271$.

[28] Njoku DN, Afuape SO, Ebeniro CN. Growth and yield of cassava as influenced by grain cowpea population density in Southeastern Nigeria. Afr. J. Agric. Res. 2010; 5: 2778-2781.

[29] Gerh SR, Lot FM, Aarh TT. The effects of different plant residues on chemical and biological properties of an alfisol. Soil Science Research. 2006; 6(4): 501 -506.

[30] Egbe OM. Effects of plant density of intercropped soybean with sorghum on competitive ability of soybean economic yield at Otobi, Benue State,Nigeria. Journal of Cereals and Oilseeds. 2010; 1:1-10.

[31] CIAT. Annual Report for Cassava Program, CIAT, Cali, Columbia. 1977; C41-492 C52.

[32] Leihner D. Agronomy and cropping systems. In: Hillocks, Rory J., Thresh, J.M. and Bellotti, A. (Ed.). Cassava: Biology, production and utilization. CABI. 2002.

[33] Midmore DJ. Agronomic modification of resource use and intercrop productivity. Field Crops Research. 1993; 34: 357-80.

[34] Borin K, Frankow-Lindberg BE. Effects of legumes-cassava intercropping on cassava forage and biomass production. J. Sustain. Agric. 2005; 27: 139-151.

[35] Nguyen PT, Ngo TD, Nguyen TM, Dinh VB, Preston T R. Improving biomass yield and soil fertility by associations of Flemingia (Flemingia macrophylla) with Mulberry (Morus alba) and cassava (Manihot esculenta) on slopping land in Bavi area.In: Proceedings of Final National Seminar-Workshop on Sustainable Livestock Production on Local Feed Resources (Editors: Reg Preston and Brian Ogle). HUAF-SAREC, Hue City. March 2003; 25 - 28.

[36] Wudil BS, Rwegasira GM, Kudra AB, Jeremiah S. Spatial and Temporal Distribution of Cassava Green Mite, Mononychellus tanajoa Bonder (Acarina: Tetranychidae) in Tanzani Archives of Current Research International. 2017; 8(3): 1-13.

[37] Jankowska B. Impact of intercropping white cabbage with Pot Marigold (Calendula officinalis L.) and French Marigold (Tagetes patula nana) on the occurrence of cabbage aphid (Brevicoryne brassicae L.), its parasitoid Diaeretiella rapae M'Intosh and predatory Syrphidae. Aphids and Other Hemipterous. Insects. 2007; 13: 199-209.

[38] Andow D. Vegetational diversity and arthropod population response. Annual Review of Entomology. 1991; 36: 561-86.

[39] Vandermeer J. The Ecology of Intercropping. Cambridge University Press, Cambridge, UK. $1989 ; 254$.

[40] Smith HA, Liburd OE. Intercropping, crop diversity and pest management. University of Florida. 2015; 862: 1-7.

[41] Schulthess F, Chabi-Olaye A, Gounou S. Multi-trophic level interactions in a cassava-maize mixed cropping system in the humid tropics of West Africa. Bull. Entomol. Res. 2004; 94: 261-272.

[42] Chabi-olaye A, Nolte C, Schulthess F, Borgemeister C. Abundance, dispersion and parasitism of the stem borer Busseola fusca (Lepidoptera: Noctuidae) in maize in the humid forest zone of southern Cameroon. Bulletin of Entomological Research. 2005a; 95 (2): 169-524 177.

[43] Onzo A, Hanna R, Sabelis MW. Temporal and spatial dynamics of an exotic predatory mite and its herbivorous mite prey on cassava in Benin, West Africa. Environmental Entomology. 2005; 34: 866 - 874.

[44] Hanna R, Onzo A, Lingeman R. Seasonal cycles and persistence of an acarine predator-prey system on cassava in Africa. Population Ecology. 2005; 47: 107-117.

[45] Teodoro AV, Klein AM, Tscharntke T. Temporally mediated responses of the diversity of coffee mites to agro forestry management. Journal of Applied Entomology. 2009a; 133: 659 - 665. 